\title{
Tackle Prostate Cancer: A Doctoral Student's Response
}

\author{
Luis E. Lacourt \\ Walden University \\ Lamar University
}

\begin{abstract}
This first hand reflection as a doctoral counseling student narrates my social action response after learning my diagnosis with prostate cancer. I discuss my experience, review facts about prostate cancer, and apply Bandura's (1977) Social Cognitive Theory, a SWOT analysis, and Eriksen's (1997) social action stages to my activities. These illustrate how I used my story and unique community resources to create awareness and raise funds through an event at a high school football game. Possibilities for additional advocacy events are also discussed.
\end{abstract}

Keywords: prostate cancer, social action, social cognitive theory, advocacy stages, counselor, survivor advocate

According to the American Cancer Society (ACS), 1 in 6 men will be diagnosed with prostate cancer in their lifetime (ACS, 2012). For African Americans (AA), this statistic is more serious as 1 in 5 men will test positive in their lifetime (ACS, 2011). It is predicted that these numbers will yield over 240,000 new cases and almost 30,000 deaths from prostate cancer in 2013 across the US. The average age of diagnosis is 67 years old. My own diagnosis came 25 years early at the age of 42 . Being raised in and native to Puerto Rico the incidence rate for my group was slightly lower than the 1 in 6 incidence of non-Hispanic Whites (NHW) in the US (Soto-Salgado et al., 2012). The death rate from prostate cancer among Puerto Rican men however is higher than that of NHW but not as high as that of AA men who are 2.4 times more likely to die from prostate cancer than White men (ACS, 2011; Soto-Salgado, et al. 2012). For the three groups prostate cancer is the second leading cause of death, after lung cancer (ACS, 2012). These statistics however alarming don't reflect the fear and loneliness that come with a cancer diagnosis.

\section{My Journey}

When I discovered I had prostate cancer, I knew immediately my life's course had taken a dramatic turn. The discovery was shocking. I had run a full marathon with my wife on Sunday and the very next day, Monday, we sat together listening to my doctor discuss my cancer and review my treatment options for the first time. I asked myself, "How did this happen?" While my doctor was optimistic about my recovery the discovery was painful. As a father to five children and husband for twenty-two years I was forced to consider their reality without a father and without a spouse. The discovery was confusing. As a dad, full-time school counselor, 
part-time student in a PhD program, and self-proclaimed athlete, the sudden discovery of cancer caused me to reconsider my values and activities. The discovery of a serious illness and the need for survival has a way of suddenly reorganizing ones priorities. The discovery was humbling. As a man, this meant perhaps there was something wrong with my sexual organs. This forced me to face some uncomfortable questions: Was something wrong with me as a man? Will cancer treatment force me to be an asexual person? What will my wife think of me? What will other men think of me if they learn I may not perform sexually or maintain urine control? As a PhD student in a Counselor Education and Supervision program, I took the opportunity to write about prostate cancer as an issue deserving greater public awareness and action. The research and writing afforded me a break from my personal distress while allowing me to explore prostate cancer as an opportunity to help others. What I learned about cancer and social change, my advocacy activities, and my personal reflections are the focus of this article.

Early detection was an advantage to me as early detection and treatment have a nearly $100 \%$ 5-year survivability rate. My doctor gave me a very positive prognosis because we had detected the cancer early but other patients are not so fortunate. The state of Ohio, where I live, recorded an average of 1,200 deaths from prostate cancer every year (ACS East Central Division, Ohio Department of Health, \& The Ohio State University, 2010). Stark County listed an average of 43 deaths per year (Ohio Department of Health, 2008). Neighbors, friends, coworkers, community members, or acquaintances would die from something as treatable as prostate cancer. Successful treatment however is facilitated by earlier screening, and detection (ACS, 2012).

\section{Masculinity}

Traditionally, seeking preventive health care is not perceived as a "manly" undertaking. Socially prescriptive norms for masculinity dictate that "men should be self reliant, strong, robust, and tough; that men should welcome danger; and that men should not reveal vulnerability" (Courtenay, 2011, p. 17). Unfortunately, values of self reliance and rugged individualism may do more harm than men realize. Courtenay presented compelling evidence that men's practice of high risk behaviors and lack of preventive self care practices have contributed to shortened lifespan for men, living five years less than women on average (US Department of Health and Human Services, 2008). For example, a study of men who were offered self care information on testicular cancer revealed that majority of the men preferred to practice traditional male roles of stoicism and avoidance rather than to visit a doctor or perform a self exam (Singleton, 2008). Galdas, Cheater, and Marshall (2005), confirmed that beliefs of "traditional masculinity" have contributed to a delay in medical help-seeking behavior. This trend is unfortunate because delays in cancer screening clearly increase the risk of not detecting cancer until it is at more advanced stages.

Sexual health concerns suggest to some men that they are somehow "unmanly" (Cushman, Phillips, \& Wasserburg, 2010). This reflects the positivist view of masculinity which indicates that masculinity is determined by the existence of male anatomy (Moynihan, 1998). Growing up in Puerto Rico with influences of machismo, I assumed a positivist perspective early in my own life. Experiencing prostate cancer, I felt myself succumb to questions about myself and my own masculinity. While I believed my masculinity was defined by more than my sexual health, the crises of cancer in my life caused me to question and explore this further. My circumstances, 
the influence of my father, my spirituality, and education helped me to accept my masculinity through a social constructivist view that posits, "male gender is practiced in social interactions and is signified by beliefs and behaviour," (Moynihan, 1998, p. 1072).

For many, a cancer diagnosis is associated with death and feelings of dread and hopelessness (Conde et. al, 2011; Pierce, Chadida, Vargas, \& Mosley 2003). These feelings go directly against the "traditional masculine" value of invincibility. The subject of prostate cancer brings together both sexual concerns and cancer fears that can cause men to agonize over the physical and emotional effects of prostate cancer on their lives. While some men pursue screening and treatment, many men opt out of screening even when such screening is available. When surveyed, men who opted out of screening reported that they did so because of cost and time inconvenience. Other men reported they opted out due to limited understanding of prostate cancer and the need for early diagnosis. Some men may also have a general lack of trust in health care professionals, a fear of a cancer diagnosis, or a concern that the screening is a threat to their "manhood" (Conde et. al, 2011; Oliver \& Grindel, 2006; Weinrich, Weinrich, Priest, \& Fodi 2003).

Additional confusion is created for men by the mixed messages from the medical profession about prostate cancer screening. The US Preventive Services Task Force (USPSTF, 2012) recently recommended against early Prostate Specific Antigen (PSA) based screening and stated that more men would be harmed by the screening than helped. This is in direct contradiction with the recommendation from the American Cancer Society (2012), and the Prostate Cancer Roundtable (2012). PSA is a protein in a man's blood created by the prostate gland. Measured through a simple blood test, it is generally believed that the higher the PSA measurement the higher risk for prostate cancer. While deaths from prostate cancer have decreased significantly since the inception of the PSA test, USPSTF discovered that higher PSA scores have contributed to unnecessary biopsies which have caused needless distress and infection in men from the procedure. While PSA is not the only screening method it is more convenient and preferred by men over the digital rectal exam. (Note: I avoided this controversy in my social change activities by recommending men discuss their screening decision with their doctors.)

\section{Personal Decisions}

I decided prior to my diagnosis that if I indeed had a positive diagnosis I would be public about the diagnostic and treatment processes to raise awareness and encourage men to consider early screening in their lives. Having watched my grandfather, father, and uncle cope and survive treatment of prostate cancer gave me confidence that I too could survive with my health, dignity, and masculinity intact. I was fortunate to have had these men in my life as role models of cancer survivorship. I hoped I could offer my own sons and the men in my community a positive look at prostate cancer survivorship. When the official diagnosis finally came my wife and I had many personal talks with each other and our kids. We discussed treatment options, my interest in social action, and my decision to be public and its possible implications for her and our five kids. Visiting with close friends was also meaningful. They understood my personal risk in being public about potential future side effects like impotence or incontinence but affirmed their friendship to me, my decision to be public, and supported my use of an online blog to record and publish my early experiences (Lacourt, 2012). Seven weeks after my diagnosis I underwent a laparoscopic radical prostatectomy to remove my prostate 
gland and the tumor contained therein. The positive prognosis after surgery was a great relief and also energized me and my commitment to bring the awareness message to other men.

\section{Social Change}

With rich roots in prevention and social advocacy (Kiselica \& Robinson, 2001; Lee \& Walz, 1998) the field of counseling endorses activities that contribute to social change as an extension of client services. The American Counseling Association (ACA) endorsed and published advocacy competencies (2003) as a guide for counselor activities and an affirmation of the counselors' role performing such actions. Taking action to change the client's social system to contribute to the wellness of other potential clients as well as systemic or community wellness is a professional and moral responsibility for counselors (Lee \& Walz, 1998). When diagnosed with prostate cancer I sought community leaders (local politicians, talk radio host/community activist, and local pastors) as well as members of our medical community (urologists) to inquire about local prostate cancer advocacy in the hopes of joining their efforts. Unanimously, they reported they were not aware of local prostate cancer advocacy efforts (Personal communications, July 2012). In a county of just over 375,000 people (U.S. Census Bureau, 2012) with 43 yearly deaths from prostate cancer, I discovered no public awareness efforts and only one support group for prostate cancer in the neighboring county. The discovery left me feeling a professional and personal responsibility to enact social change by raising awareness among men about the treatability of prostate cancer and of the importance to engage in earlier screening.

I hoped that being public about my own story would break the silence in our community, share a positive example of prostate cancer survivorship, and raise awareness that would cue men to get screened for prostate cancer. While preparing for my own treatment I explored various community outreach activities, reviewed social change theories, collaborated with various community members, and sought counsel on starting a nonprofit. I discovered I was unintentionally following Eriksen's (1997) seven stages of advocacy. While Eriksen applied her advocacy stages to the counseling profession I utilized the stages as a guide for my own activities. This article will outline my activities according to these stages. Bandura's (1977) social cognitive learning theory will serve as a theoretical basis for the social change activities described. I also explored the feasibility of our strategy through a Strengths, Weaknesses, Opportunities, and Threats (SWOT) analysis.

\section{Theory}

Social cognitive learning theory (SCLT; Bandura, 1977) explained that individuals may gain a personal expectation of success by watching others succeed over similar obstacles. I watched my own father, uncle, and grandfather endure and survive prostate cancer, which gave me a sense of confidence that I too could do the same. In my eyes their masculinity was not diminished because of their illness, instead I gained respect for their strength and honesty. SCLT holds that people also learn through verbal persuasion of a therapist, role model, television show, friend, family, teacher, nurse, or survivor advocate (Bandura, 1977; Bandura, 2009; Holt et al., 2009; Maliski, Clerkin, \& Litwin, 2004; Nivens, Herman, Weinrich, \& Weinrich, 2001). My father's prompting to get screened was the reason I participated in early screening which led to the early discovery. Efficacy expectation is the belief that one can cope with or follow through on what is required to be successful (Bandura, 1977). Bandura (1977) explained 
that people withdraw and avoid a situation that seems too threatening or potentially overwhelming. This is consistent with men's decisions to opt out of an available cancer screening and the reasons men gave for avoiding cancer screening (Conde et. al 2011; Oliver \& Grindel, 2006; Weinrich, Weinrich, Priest, \& Fodi 2003). By raising awareness in a public forum, I hoped to influence the self efficacy of listeners through vicarious experience and verbal persuasion. By being in the company of prostate cancer survivors and hearing a survivorship story, I hoped men would see a visual representation of how prostate cancer is treatable and how men can cope with it.

\section{Seven Stages of Advocacy}

Eriksen's (1997) seven stages of counselor advocacy are (a) Professional Identity, (b) Problem Identification, (c) Resource Assessment, (d) Strategic Planning, (e) Advocacy Training, (f) Taking Action, and (g) Victory Celebration, Evaluating Outcomes, Regrouping after Losses. These stages offered a natural progression to my social change activities and served as a guideline to anticipate upcoming steps.

\section{Professional Identity}

I serve as a school counselor but am also licensed as a professional counselor. The values of education, prevention, client wellness, and client empowerment are all values that resonate with me personally and professionally. Kiselica and Robinson (2001) inspired counselors "to identify some human condition that moves them so deeply that it inspires a personal moral imperative to make this world a better place by advocating for others in a manner that suits their personality" (p. 396). My cancer diagnosis became an opportunity to empower men to make educated healthcare decisions. I knew that my experience and understanding could also help me be a voice for the men who are currently suffering privately with prostate cancer.

\section{Problem Identification}

The identified problem was the gap in prostate cancer advocacy efforts in our community. The absence of a public voice reinforced a systemic silence about prostate cancer that permitted men to remain ignorant about prostate cancer, encouraged their fears, and allowed their questions to go unanswered.

\section{Resource Assessment}

Adequate resources are necessary to facilitate innovative change implementation (Ensminger \& Scurry, 2008). To ensure we had the needed resources, we utilized strategic communication strategies for health awareness, natural events in our community, volunteers, and the cooperation of other local organizations. With Stark County being the birth place of professional football and home to the Pro-Football Hall of Fame, community high school games get significant community attention and local media coverage. Football games in our community are embedded into the fabric of our community's identity so they occur naturally, are heavily attended by men, and offer a strategic opportunity to deliver health based message to men. High school sporting events were an inexpensive and readily accessible resource at my disposal so I considered additional venues like volleyball, basketball, and wrestling events. After 
considering the culture of our community, the size of the audience at the event, and the timing of my recovery I felt that a football game would be the most effective launch for this message.

As a school counselor, I began conversations with my school district of employment (Jackson Local Schools in Massillon, Ohio) and my school district of residence (Perry Local Schools in Massillon, Ohio) to explore the feasibility of using one of these games to deliver a public health message. Both schools already had experience promoting breast cancer awareness at volleyball games, and basketball games. Their October $19^{\text {th }}$ match up would offer both schools an innovative opportunity to promote prostate cancer awareness.

We brought together local school districts, a local urology office, and hospital into planning the event and offered them positive publicity. Eriksen (1997) defined political expertise as the ability to bring together organizations that would not normally work together under a common cause by offering them an opportunity to meet their needs. We discovered a way to generate revenue by selling a "Tackle Prostate Cancer" shirt to students that also included the logos of local business sponsorships. The revenues would fund the cost of the event and future awareness efforts. While initially apprehensive, eleven local companies gave sponsorship commitments in exchange for shirt and event publicity totaling to $\$ 9,500$ in pre-event money commitments. By offering organizations a win-win opportunity we discovered more resources than we had anticipated. Friendships, local radio show, and social media were also important resources that informed the general public of our event and invited them to attend.

\section{Strategic Planning and SWOT Analysis}

The team of stakeholders selected the event date, named the event "Tackle Prostate Cancer," and identified feasible strategies for promoting and communicating a health based message. They asked me to share my story of prostate cancer recovery and introduce other prostate cancer survivors from the fifty yard line during halftime. Whether the message was through a public service announcement, the presence of prostate cancer survivors, a testimonial, shirts being worn by students, cards with statistics, or the presence of a medical staff at a booth, the message of prostate cancer awareness would be clear to all.

SWOT is a strategic planning tool utilized to aid our decision making by exploring the Strengths, Weaknesses, Opportunities, and Threats involved in social change. SWOT analysis is typically reflected in a matrix (Jyothi, Babu, \& Krishna, 2008) as demonstrated on Table 1 highlighting the potential benefits or harms on the horizontal axis, and the internal vs external attributes on the vertical axis.

Strengths. As a school counselor in one district and a resident of the other, I strategically utilized the access I had within both districts. We created videos that would be displayed at both districts during morning announcements that shared my story with them, informed them about prostate cancer, invited them to the game, and promoted our shirt.

Weaknesses. The event itself was very inexpensive to coordinate since we had a free facility, and a captive audience. However, there were details that would require financing: the shirts, blue socks for the players, blue paint for the end zones, and event signage. Our fundraising strategy of a "Tackle Prostate Cancer" shirt was simple but unfunded initially. We needed to 
order shirts to raise money but we had no initial funds with which to place a deposit for ordering the shirts.

Table 1

SWOT Analysis of Tackle Prostate Cancer Event

\begin{tabular}{|c|c|c|}
\hline & $\begin{array}{c}\text { Helpful } \\
\text { to achieving the objective }\end{array}$ & $\begin{array}{l}\text { Harmful } \\
\text { to achieving the objective }\end{array}$ \\
\hline $\begin{array}{l}\text { Internal } \\
\text { (attributes of } \\
\text { the event) }\end{array}$ & $\begin{array}{l}\text { Strengths } \\
\text { - } \quad \text { Pursuit, discovery, and } \\
\text { - } \quad \text { organization of resources. } \\
\text { - } \quad \text { Compership / team } \\
\text { - } \quad \text { Event driven by altruistic values } \\
\text { - } \quad \text { Successful strategy } \\
\text { - } \quad \text { Simple and clear message } \\
\text { - } \quad \text { Access to communicate with } \\
\quad \text { students from two districts }\end{array}$ & $\begin{array}{l}\text { Weaknesses } \\
\text { - } \quad \text { No pre-event operating funds } \\
\text { - } \quad \text { Inexperience fundraising } \\
\text { - } \text { fundraising revenue - shirt sales, } \\
\text { and sponsorships. } \\
\text { - Inexperience organizing an event of } \\
\text { that size } \\
\text { - } \quad \text { Resources - many stakeholders } \\
\text { wanting a say in the event }\end{array}$ \\
\hline $\begin{array}{l}\text { External } \\
\text { (attributes of } \\
\text { the event) }\end{array}$ & $\begin{array}{l}\text { Opportunities } \\
\text { - Community vacuum for prostate } \\
\text { cancer advocacy } \\
\text { - } \quad \text { Community support } \\
\text { - } \text { Naturally occurring community } \\
\text { - } \text { Participation from many } \\
\text { stakeholders }\end{array}$ & $\begin{array}{l}\text { Threats } \\
\text { - } \quad \text { Adult and student ignorance } \\
\text { - } \quad \text { USPSTF recommendation to not use } \\
\text { PSA screening } \\
\text { - } \quad \text { Competition from other charities } \\
\text { - Mistrust for charities seeking money }\end{array}$ \\
\hline
\end{tabular}

Opportunities. I initially thought that the lack of existing prostate cancer advocacy in our community was an obstacle but it really turned out to be an opportunity. I discovered many individuals who said, "We hear about breast cancer all the time. It's about time someone did something for men" (Personal communications, September 2012). This vacuum allowed us to share our distinct message and tap into the energies of survivors, and their families who have not had an avenue to participate in community advocacy for prostate cancer.

Threats. Our two biggest threats to the project were ignorance of prostate cancer and competition from other charities. Public ignorance about prostate cancer contributed to the lack of concern, urgency, and misinformation. Many men have asked me "What does your prostate do? Do you need it?" (Personal communications, August 2012) This ignorance creates an obstacle for individuals considering screening, reinforces apathy about the subject, and allows for stigma and discomfort in discussion.

While we anticipated that competition from other charities might be an external factor but we did not anticipate the push back we received. Unfortunately, the local breast cancer awareness group approached the host school administration after our event was scheduled to express their disappointment that our event would be held during October's breast cancer awareness month, and asked that our date be changed so they could hold their own fundraiser at that game. 
When we scheduled the event, my own school of employment (Jackson), was supportive but turned down the prostate cancer football game at their facility citing that they were already scheduled to host a breast cancer awareness game in September. This caused me to approach my district of residence, Perry. We selected the October, Jackson vs Perry game on two factors, my anticipated recovery from the August surgery and my employment with the opposing school (Jackson). Living in the promoting district while working in the opposing district facilitated our efforts to cross promote and sell the same shirt to both locations. The school administration affirmed their commitment to our event but unfortunately the controversy continued. Only individuals who worked closely with the organization of this event appreciated the irony of two events held during conflicting months. At Jackson I could not host a prostate cancer awareness game during prostate cancer awareness month (September) because they had already scheduled a breast cancer awareness game in September. The Perry local breast cancer awareness group couldn't hold their breast cancer awareness game on the proper month (October) because of our prostate cancer game in October.

Social Justice. Men have traditionally held roles of authority, in contrast to women who have had to advocate for their rights. Ironically, the competing causes of prostate cancer and breast cancer present a disparity in services, research, and awareness for men and this deserves exploration. Breast cancer awareness has not only been normalized but has become fashionable with sporting goods stores selling pink gear throughout the year. Local high schools have been hosting breast cancer awareness football games, basketball games and volleyball games for years. These activities are important as they have brought research monies and attention to a worthy cause. Unfortunately prostate cancer awareness lags behind and society's ignorance is perpetuated.

While there is a higher yearly incidence of prostate cancer than breast cancer (ACS, 2012), the National Cancer Institute (NCI) spent $\$ 625$ million dollars on breast cancer research in 2011 while only spending $\$ 288$ million during that same time on prostate cancer (NCIa, 2012; NCIb, 2012). Us Too, a national prostate cancer advocacy organization, estimated that there have been 2.6 times as many news stories about breast cancer than about prostate cancer (Wheeler, nd). They surveyed and found that during 1996-2006, ABC news aired 895 stories on breast cancer as opposed to 228 stories on prostate cancer. During that same time CBS news had 498 stories on breast cancer and 174 stories on prostate cancer (Wheeler, nd). The lack of research and media coverage create a disparity that perpetuates ignorance and lack of urgency among men.

\section{Advance Training}

Eriksen's fifth stage of advocacy served as a review for the staff, volunteers, and prostate cancer survivors to remain on target about the message of awareness. They understood we were not there to advocate for a certain treatment, to make promises about the validity of one treatment over another, or to recommend one medical practice over another but to instead deliver a message of early screening awareness. Very specific questions about treatment were referred to medical personnel. Stages six and seven were the actual event and the follow-up review of the event. 


\section{Taking Action}

The event itself went remarkably well. Steady rain dampened the attendance to just over 3,000 instead of the anticipated 5,000. Teams of volunteers staffed the booth, covered their assigned entrances to ensure all in attendance received informational cards about prostate cancer, and doctors were on hand to answer questions. We began the evening with over 5,000 pieces of literature, and we finished the night with under a thousand pieces left. Not only did every attendee receive a piece of literature, but many received multiple pieces of literature when they entered the stadium. I worked directly with the prostate cancer survivors to meet them at our designated location, review our game plan, answer their questions, and ensure their accommodations were met. From my earlier phone conversations with them, I determined that I not only wanted to present the community with a health based message but I also wanted to honor these men by giving them a positive, enjoyable experience at this event.

Cheerleader's chants from the sidelines, referee whistles, football pads cracking against one another, and crowds cheering were also accompanied by the announcer's message: "Did you know? 1 in 6 men are diagnosed with prostate cancer during their lifetime. Early detection is the key. Men, have a talk with your doctor to determine what screening is right for you or visit with the medical professionals in the Aultman tent." Between the large signs at the entrance, the handouts at the gates, and the public service announcements it was hard to miss the theme of the evening. The light blue marketing color of prostate cancer awareness was displayed in the football players' blue socks, the field end zones, and the "Tackle Prostate Cancer" fundraising shirts worn by hundreds of students and adults. Blue banners decorated the field during the halftime presentation of survivors, and the central informational tent was also a blue color.

Twenty-four prostate cancer survivors gave their time to come to the game and stand on the 50 yard line to represent survivorship over cancer. During halftime I shared my testimony and introduced the survivors alphabetically. In the rain each of the men walked across the fifty yard line. When their name was called they each looked up at the audience, raised their arms in victory, and received the audience applause. The men were victorious over cancer and stood together as a visual representation of courage and survivorship. We did not relinquish our masculinity when we learned of our diagnosis; we stepped forward, and fought back! As I stepped off the field the athletic director stated to me, "There is a lot of courage on that field." I thanked, shook hands, and hugged each of the men as they walked off the field. We felt like a football team that had just beat its cross-town rival.

\section{Victory Celebration, Evaluating Outcomes}

A barbecue restaurant sponsored our event and invited our survivors to the restaurant after the game for a free meal. This meal gave us our first chance to review the event and get feedback from our survivors. The review considered the gains made, how the event was a success as well as how the event may have come short of expectations. The survivors expressed gratitude for the event and shared their interest in participating again in future events. I received comments like, "Great work here," "We really need to do more to raise prostate awareness." (Personal Communications, October, 2012). 
I also used that evening to review the event with our fundraiser. In the end after expenses we raised over $\$ 11,000$ in sponsorships, shirt sales, and donations. We handed out 4,000 pieces of literature to 3,000 people in attendance and sold almost 700 shirts. Subsequent meetings with the urology office and the schools revealed to me they were surprised with how well the event took place and with how well the message was received. They described the conversations held with attendees who approached the informational booth or the school administration during the event. Comments like "Seeing those men on the 50 yard line really made it more real to me" supported our use of SCLT. These reports, the audience reception, and the feedback I have received since the event have indicated that, when utilized at a male dominated sporting event, the SCLT may be a good approach for offering men a health based message.

\section{Additional future activities}

The discovery of prostate cancer in my body and subsequent "clean" blood reports from my doctor have heightened my interest for this and other types of prostate cancer advocacy activities. Holt et al. (2009) developed a spiritually-based intervention for church going African American (AA) men to increase informed decision making for prostate cancer screening. Luque et al. (2010) explored the feasibility of training AA barbers to deliver a prostate cancer message to their customers in a barbershop. I started a prostate cancer support group for men and their families at the local urology office to establish the first prostate cancer support group in the county. I organized a board for the nonprofit, conducted additional awareness events, and hope to develop a mechanism to pay for screenings for men who cannot afford it. Wray et al. (2009)

and Kovtun, Engh, and Jatoi (2008) supported the role of prostate cancer survivor as a valuable advocate to generate awareness of cancer screenings and to work with current prostate cancer patients in treatment. With time, perhaps the men in our support group will feel so empowered that they will want to participate in advocacy efforts. I am grateful that such an experience for me has become a source of help for others.

\section{Implications for Social Action}

Several components came together to make this a successful event. Relationship building counseling skills helped me to recruit others, organize a team, and facilitate social action activities. A sequential model like Eriksen's stages helped me assess our progress and anticipate our activities in the next stages. Local resources helped us bring together more participants, larger audience, and more money for our cause. The gap in local advocacy and the disparity on a national level inspired us through this project. An existing event with a target audience provided us a natural venue for our message. A simple straight-forward message focused our communications.

High school sporting events have an advantage in that they can help raise awareness of a cause to the local community but they also have their limitations. While a high school football game helped us reach a broad audience of parents, grandparents, school faculty, and students, it did not directly address the focus group of adult men. These events are also limited in the audience outreach and their fund raising capacity. We chose to keep our efforts and funds local, but future counselors may leverage their efforts by partnering with a national advocacy organization, a political representative, or celebrity who may be sympathetic to such a cause. These partnerships may take more work, but they may also yield more resources, media attention, publicity, and momentum, and to their cause. 
Counselors considering social action would be wise to operate from a social action model, utilize their relational skills, create a team, perform a SWOT analysis, and focus the message and purpose. I was supported by a number of wonderful individuals through the process who made the event possible. They reminded me that meaningful work is rarely easy (Personal Communications, October, 2012).

\section{Conclusion}

Prostate cancer is the second leading cause of cancer death for men in the US. While there is a greater yearly incidence of prostate cancer than breast cancer, there exists a disproportionate amount of research spending and media attention given to breast cancer. This disparity was also reflected locally in the lack of local advocacy or local support groups. Upon the discovery of my own cancer I organized and conducted an awareness event called "Tackle Prostate Cancer." I applied Bandura's SCLT, a SWOT analysis, and Eriksen's (1997) social action stages to organize and conduct social action in our community that raised awareness, raised money, and offered men a relevant health related message. We found success utilizing an already existing male driven sporting event as a venue for prostate cancer awareness.

I never dreamed that developing prostate cancer would bring opportunities like starting a nonprofit, organizing a football game for awareness, interviewing with radio to get the message out, raising moneys to help less fortunate, or conducting a support group. Hopefully by hearing my story and encouragement more men will take initiative to have earlier conversations with their doctors and face the uncertain fear of prostate cancer.

\section{Contact Information:}

Luis E. Lacourt

Prostate Awareness \& Cancer Support

Massilon, $\mathrm{OH}$,

Email: LuisL@pacsohio.org

\section{References}

American Cancer Society. (2011). Cancer facts \& figures for African Americans. Retrieved from http://www.cancer.org/acs/groups/content/@epidemiologysurveilance/documents/docu ment/acspc-027765.pdf

American Cancer Society. (2012). What are the key statistics about prostate cancer? Retrieved from http://www.cancer.org/Cancer/ProstateCancer/DetailedGuide/prostate-cancer-keystatistics

American Cancer Society East Central Division, Ohio Department of Health, \& The Ohio State University. (2010). Ohio Cancer facts \& figures 2010. Retrieved from http://www.odh.ohio.gov/ /media/ODH/ASSETS/Files/opi/cancer\%20incidence\%20surv eillance\%20system\%20ociss/ohiocancerfactsandfigures2010.ashx 
American Counseling Association. (2003). Advocacy Competencies. Retrieved from http://www.counseling.org/resources/competencies/advocacy_competencies.pdf

American Urological Association. (2012). AUA speaks out against USPSTF recommendations. Retrieved from http://www.auanet.org/content/health-policy/government-relations-andadvocacy/in-the-news/uspstf-psa-recommendations.cfm?WT.mc_id=PRT6660MKT

American Urological Association Foundation. (2012). Know your stats: About us. Retrieved from http://www.knowyourstats.org/AboutUs.cfm

Bandura, A. (1977). Self-efficacy: Toward a unifying theory of behavioral change. Psychological Review, 84(2), 191-215. doi:10.1037/0033-295x.84.2.191

Bandura, A. (2009). Social cognitive theory goes global. Psychologist, 22(6), 504-506.

Conde, F. A., Landier, W., Ishida, D., Bell, R., Cuaresma, C. F., \& Misola, J. (2011). Barriers and facilitators of prostate cancer screening among Filipino men in Hawaii. Oncology Nursing Forum, 38(2), 227-233. doi:10.1188/11.ONF.227-233

Courtenay, W. (2011). Dying to be men: Psychosocial, environmental, and biobehavioral directions in promoting the health of men and boys. New York, NY: Routledge.

Cushman, M. A., Phillips, J. L., \& Wassersug, R. J. (2010). The language of emasculation: Implications for cancer patients. International Journal of Men's Health, 9(1), 3-25. doi:10.3149/jmh.0901.3

Ensminger, D. C., \& Surry, D. W. (2008). Relative ranking of conditions that facilitate innovation implementation in the USA. Australasian Journal of Educational Technology, 24(5), 611626.

Eriksen, K. (1997). Making an impact: A handbook on counselor advocacy. New York, NY: Routledge.

Galdas, P. M., Cheater, F., \& Marshall, P. (2005) Men and health help-seeking behaviour: literature review. Journal of Advanced Nursing 49(6), 616-623. doi:10.1111/j.13652648.2004.03331.x

Holt, C. L., Wynn, T. A., Southward, P., Litaker, M. S., Jeames, S., \& Schulz, E. (2009). Development of a spiritually based educational intervention to increase informed decision making for prostate cancer screening among church-attending African American men. Journal of Health Communication, 14(6), 590-604. doi:10.1080/10810730903120534

Jyothi, B., Babu, G. R., \& Krishna, I. (2008). Object oriented and multi-scale image analysis: Strengths, weaknesses, opportunities and threats-A review. Journal of Computer Science, 4(9), 706-712. doi:10.3844/jcssp.2008.706.712 
Kiselica, M. S., \& Robinson, M. (2001). Bringing advocacy counseling to life: The history, issues, and human dramas of social justice work in counseling. Journal of Counseling and Development, 79(4), 387-397. doi:10.1002/j.1556-6676.2001.tb01985.x

Kovtun, I., Engh, J., \& Jatoi, A. (2008). A survey of patient advocates within the National Cancer Institute's Prostate Cancer SPORE Program: who are they? What motivates them? What might they tell us? Journal of Cancer Education, 23(4), 222-225. doi: $10.1080 / 08858190802188768$

Lacourt, L. (2012). My journey. Retrieved from http://luisprostatecancer.wordpress.com/

Lee, C. C., \& Walz, G. R. (Eds.). (1998). Social action: A mandate for counselors. Alexandria, VA: American Counseling Association.

Luque, J. S., Rivers, B. M., Kambon, M., Brookins, R., Green, B., \& Meade, C. D. (2010). Barbers against prostate cancer: A feasibility study for training barbers to deliver prostate cancer education in an urban African American community. Journal of Cancer Education, 25(1), 96-100. doi:10.1007/s13187-009-0021-1

Maliski, S., Clerkin, B., \& Litwin, M. (2004). Describing a nurse case manager intervention to empower low-income men with prostate cancer. Oncology Nursing Forum, 31(1), 57-64. doi:10.1188/04.ONF.57-64

Moynihan, C. (1998). Theories in health care and research: Theories of masculinity. British Medical Journal, 317(7165), 1072-5. Retrieved from http://search.proquest.com/docview/204028796?accountid=14872

National Cancer Institute. (2012a). A snapshot of breast cancer. Retrieved from http://www.cancer.gov/researchandfunding/snapshots/breast.

National Cancer Institute. (2012b). A snapshot of prostate cancer. Retrieved from http://www.cancer.gov/researchandfunding/snapshots/prostate.

Nivens, A. S., Herman, J., Weinrich, S. P., \& Weinrich, M. C. (2001). Cues to participation in prostate cancer screening: A theory for practice. Oncology Nursing Forum, 28(9), 14491456.

Ohio Department of Health. (2008). Stark County cancer profile. Retrieved from http://www.odh.ohio.gov/ /media/ODH/ASSETS/Files/opi/cancer\%20incidence\%20surv eillance\%20system\%20ociss/stark.ashx

Ohio High School Athletic Association. (2010). Athletic directors manual 2010 football. Retrieved from http://www.ohsaa.org/sports/ft/boys/default.asp

Oliver, J., \& Grindel, C. (2006). Beliefs and attitudes about prostate cancer and prostate cancer screening practices among rural African American men. Oncology Nursing Forum, 33(2), 454. 
Pierce, R., Chadiha, L., Vargas, A., \& Mosley, M. (2003). Prostate cancer and psychosocial concerns in African American men: literature synthesis and recommendations. Health \& Social Work, 28(4), 302-311. doi:10.1093/hsw/28.4.302

Prostate Cancer Roundtable. (2012). Media release: New PSA recommendations from U.S. Preventive Services Task Force are a disservice to men. Retrieved from http://www.prostatecancerroundtable.net/media/media-release-52112/

Singleton, A. (2008). It's because of the invincibility thing: Young men, masculinity, and testicular cancer. International Journal of Men's Health, 7(1), 40-58. doi:10.3149/jmh.0701.40

Soto-Salgado, M., Suárez, E., Torres-Cintrón, M., Pettaway, C. A., Colón, V., Ortiz, A. P. (2012). Prostate cancer incidence and mortality among Puerto Ricans: An updated analysis comparing men in Puerto Rico with US racial/ethnic groups. Puerto Rico Health Sciences Journal, 31(3), 107-113.

Toporek, R. L., Lewis, J. A., \& Crethar, H. C. (2009). Promoting systemic change through the ACA advocacy competencies. Journal of Counseling and Development, 87(3), 260-268. doi:10.1002/j.1556-6678.2009.tb00105.x

U.S. Census Bureau. (2012). State \& county quickfacts: Stark County, Ohio, 2011. Retrieved from http://quickfacts.census.gov/qfd/states/39/39151.html

U.S. Department of Health And Human Services, (2008). United States Life Tables, 2008. National Vital Statistics Reports, 61(3), 1-64. Retrieved from www.cdc.gov/nchs/data/nvsr/nvsr61/nvsr61_03.pdf

U.S. Preventive Services Task Force. (2012). Screening for prostate cancer: Current Recommendation statement. Retrieved from http://www.uspreventiveservicestaskforce.org/prostatecancerscreening.htm

Weinrich, S. P., Weinrich, M. C., Priest, J., \& Fodi, C. (2003). Self-reported reasons men decide not to participate in free prostate cancer screening. Oncology Nursing Forum, 30(1), E12-E16. doi:10.1188/03.onf.e12-e16

Wheeler, E. M. (nd). Challenging the prostate cancer gap [PowerPoint Slides]. Retrieved from http://msdh.ms.gov/msdhsite/_static/resources/3676.pdf

Wray, R. J., McClure, S., Vijaykumar, S., Smith, C., Ivy, A., Jupka, K., \& Hess, R. (2009). Changing the conversation about prostate cancer among African Americans: Results of formative research. Ethnicity \& Health, 14(1), 27-43. doi:10.1080/13557850802056448

Luis E. Lacourt is a doctoral student at Walden University in their Counselor Education and Supervision program. He works as a school counselor at Perry High School in Massillon, Ohio, and teaches school counseling classes at Lamar University. As president of Prostate Awareness and Cancer Support, he continues to engage in community prostate cancer outreach activities. 